\title{
GENDER EARNINGS DIFFERENTIALS IN TOTAL PAY, BASE PAY, AND CONTINGENT PAY
}

\author{
KEITH W. CHAUVIN and RONALD A. ASH*
}

\begin{abstract}
Using data from a 1988 survey of business school graduates, the authors analyze gender differentials in earnings by form of pay-total pay, base pay, and contingent pay-with controls for human capital, occupation, job level, and individual characteristics. The results indicate that within narrowly defined occupations and jobs, most of the unexplained difference in total pay between the men and women in the sample was due to gender differences in the portion of pay that was contingent on job performance. The greater importance of contingent pay in the earnings of the men than of the women may reflect differential treatment of men and women by firms, gender differences in performance, gender differences in risk preferences, or some other sorting mechanism.
\end{abstract}

$\mathbf{M}$ ost attempts to explain the gap in pay between men and women have focused on sets of explanatory variables included in wage equations. Typically, annual earnings or hourly wages are regressed on human capital and other productivityrelated measures of the job and individual. These variables account for part but not all of the gender-pay gap. The unexplained portion of the pay gap is often interpreted as the effect of market discrimination. Since it is possible that the failure of these regressions to explain all of the pay gap is due to omitted productivity-related variables, how-

${ }^{*}$ Keith Chauvin is Associate Professor of Business and Ronald Ash is Professor of Business, both at the University of Kansas. This research was supported, in part, by funds from the General Research Fund of the University of Kansas. The authors thank James Guthrie, Judy Olian, and Sara Rynes for helpful comments on an earlier draft of the paper. ever, researchers are constantly searching for better measures of productivity. So far, better measures of the explanatory variables have not significantly reduced the unexplained portion of the pay gap.

In this paper we attempt to move toward an understanding of the causes of the unexplained portion of the gender-pay gap by exploring a different dimension of the gap. Rather than simply trying to account for the gender difference in pay, we analyze how the pay gap varies by type of pay. The data set we use, drawn from a 1988 survey of business school graduates, includes measures of individuals' base pay and pay contingent on job performance. We test

Copies of the data and programs used to generate the results will be available after May 1995 for purposes of replication from the authors at the School of Business, University of Kansas, Lawrence, Kansas 66045 .

Industrial and Labor Relations Review, Vol. 47, No. 4 (July 1994). (c) by Cornell University. $0019-7939 / 94 / 4704 \$ 01.00$ 
whether the unexplained portion of the pay gap varies between these two types of pay. The processes and managerial practices that determine base pay are very different from those that are used to determine performance-contingent pay. Because of these differences, we argue that understanding how the pay gap and the unexplained portion of the gap are distributed between these two forms of pay is potentially useful for identifying or narrowing the possible causes of the pay gap.

\section{Research on the Gender-Pay Gap}

Studies of why men earn, on average, significantly more than women continue to find that a large percentage of the differences in earnings and wages cannot be explained by differences in human capital, demographic characteristics, or firm characteristics. Even after controlling for broad occupational categories, approximately $50 \%$ of the earnings differential cannot be accounted for by differences in endowments between men and women. Since measures that allow a comparison of productivity across workers, jobs, occupations, and firms are not available, the approach used in almost all attempts to explain the "unexplained" portion of the pay gap has been to try to obtain marginally better proxies for productivity. The quality of education, actual labor market experience, interruptions in labor market experience, and firm tenure, for example, have been included in recent studies of the pay gap. Measures of production in the household have also been included in earnings models. Responding to the argument by Becker (1985) that gender differences in household responsibilities may account for part of the pay gap, Hersch (1991), for example, used a new data set that included measures of the intensity of household and child care duties. She found that these factors, and specific job characteristics, added very little to the explanation of the pay gap.

Only when control variables for detailed occupational category or the job are included in the estimates of the gender-pay gap does the unexplained portion of the gap decline significantly. Reviews of the literature show convincingly that most of the gender gap in pay, holding constant the traditional measures of human capital, occurs across occupations. Furthermore, nearly all of the relatively small difference in pay that exists within narrowly defined jobs and occupations occurs across firms (Blau 1977; Groshen 1991). Studies that look at pay differences within jobs, within firms, find little or no gender difference in pay. Gerhart (1990), for example, found that when human capital and other relevant factors were controlled for, the female/male pay ratio within jobs in a single firm was between .95 and .98 . We know from the existing research, therefore, that nearly all of the difference in pay between men and women is due to women being disproportionately represented in lowerpaying occupations and in lower-paying firms within occupations. This conclusion is supported by reviews of recent studies of the gender-earnings gap (for example, Cain 1986; Blau and Ferber 1987a; Gunderson 1989).

The extent to which market discrimination is or is not a cause of the differences in mobility across jobs and in the occupational distribution between men and women cannot be inferred from these studies. Although the findings indicate that much of the gender difference in pay occurs across occupations and jobs, Blau and Ferber (1987a, 1987b) pointed out that when controls such as occupation or job are included in the estimate of the wage equation, the gender-pay gap tends to be underestimated. This underestimation occurs because the choice of job or occupation has likely been influenced by market discrimination. If the rate of return on educational investments in engineering is lower for women than for men because of market discrimination against female engineers, for example, then women will invest less than men in this type of education. In this case, the "choice" of women not to go into engineering is partly the result of market discrimination. At best, a lower bound estimate of the effects of discrimination is obtained when variables that may be influ- 
enced by discrimination through feedback effects are included in the analysis.

To better understand the causes of the pay gap, and not just the size of the gap, it is necessary to understand how the choices of occupations and firms differ between men and women, how firms' recruitment, selection, promotion, and pay determination practices vary across jobs, and how these practices vary across firms. If market discrimination is a significant factor in the segregation of women across jobs or across firms, then these practices are the mechanisms through which discrimination and the related feedback effects occur.

In this study we ask whether or not, within narrowly defined occupations or jobs, the gender-pay gap varies with the form of pay. Is the level of pay the only difference between jobs in high-paying firms employing men and jobs in lower-paying firms employing women? One characteristic that nearly all of the studies of the pay gap have in common is their use of the level of hourly wages or earnings as the dependent variable. Although there is a growing body of empirical literature focusing on compensation and the incentive effects of various forms of pay (for example, Lazear 1986; Abowd 1990; Brown 1990; Kahn and Sherer 1990 ), only one attempt has been made to test whether the gender-pay differential varies across different forms of pay. This fact is partly due to the nature of the data sets that are regularly analyzed for explanations of the gender-pay differential. Most, if not all, large public data sets provide measures of total earnings or hourly wages, but they do not provide the information necessary to distinguish among the forms of pay.

The one study that does provide some information on differences in the form of pay is Goldin (1986). Using data from 1890 to 1940 for manufacturing and clerical jobs, Goldin found that women were more likely than men to be paid piece rates. This finding is consistent with a model in which workers with high turnover rates are sorted into jobs or occupations with piece rates as opposed to time rate methods of pay determination. Goldin's model shows that this sorting reduced monitoring costs associated with higher turnover rates.

The analysis in this paper uses data from a survey in which respondents reported their total annual pay, their base pay, and the part of their total pay that was contingent on their job performance. Examples of contingent pay are sales commissions and performance bonuses. Using this data set, we estimate the gender gap in total pay, base pay, and contingent pay. We attempt to answer the simple question: does the unexplained portion of the gender gap in total pay, within jobs, vary between base pay and contingent pay?

\section{Base Pay and Contingent Pay}

The important respect in which this paper departs from previous studies is our disaggregation of the dependent variable, total pay, by form of pay. Total pay equals the sum of base pay and contingent pay. Base pay is the part of the total salary or pay that does not depend in a given year on the individual's job performance. Base pay is determined largely by the level of an individual's job in the firm's hierarchy. Changes in base pay are determined by year-to-year adjustments from merit pay awards and from promotions (demotions) to higher (lower) job levels. Merit pay adjustments are based on a supervisor's performance evaluation of the individual during a given period of time; they become a permanent part of the base pay beginning in the next pay period. Base pay, therefore, varies with job performance over time, but not during a given pay period. Although merit pay adjustments account for the variance in base pay within a specific job level in a given firm, most of the variance in base pay reflects differences among jobs in their levels in the hierarchy.

Contingent pay awards such as bonuses, commissions, and profit and gain sharing awards, on the other hand, depend primarily on the individual's job performance, or the performance of a group in the case of gain sharing and profit sharing, during a given period of time. When the individual (or the individual's group) achieves a pre- 
specified performance standard, he or she receives a pre-specified pay award. Unlike merit pay adjustments, these pay awards do not become part of the base pay and are paid in subsequent time periods only if the individual (or group) continues to achieve the performance standard. All else equal, as contingent pay increases as a percentage of total pay, the individual's risk of shortrun variations in pay as a result of variations in his or her job performance also increases.

This difference between base pay and contingent pay allows for a unique test of the extent to which the gender-pay gap varies with the amount of risk in pay that is borne by the individual. If firms discriminate against women because of a priori expectations that women are more likely than men to leave the firm during any given time period for family or other non-job-related reasons, then firms may attempt to force women to bear more of the risk for shortrun variations in their job performance. This relationship would be consistent with the findings of Goldin (1986). The expected relationship between the genderpay gap and the form of pay, however, is not clear. Systematic differences in risk preferences between men and women, for example, could cause women to select into jobs and firms with less pay risk than the jobs and firms selected by men, or vice versa. Subich et al. (1989), based on a study of college juniors and seniors who were about to enter the labor market, found that women were less likely to take risks in their occupation and job choices than were men. Based on their review of the literature, they also provided a substantial amount of evidence that women are more risk-averse than men in their behavior in the labor market and in other activities.

The purpose of this study is not to estimate the effects of discrimination. We attempt, instead, to estimate the extent to which the unexplained portion of the pay gap varies between base pay and contingent pay. Since the base pay/contingent pay mix is likely to vary with the level of the job in the firm, we hold constant the job level by including controls for job mobility and access that may result from choices and abilities of individuals, barriers to job mobility confronting women, feedback effects from such discrimination, or some combination of these factors. Controlling for these endogenous factors is likely to result in underestimation of the effects of discrimination. Once we control for the job level, however, we will be able compare the remaining unexplained portion of the pay gap in base pay with the unexplained portion in contingent pay. If the gender-pay gap does not vary by form of pay, then we would expect, controlling for the job level, that the unexplained percentage of the gap would be the same for base pay and contingent pay.

\section{The Data}

The data analyzed in this paper come from a survey of business school graduates of two large state universities. This data set was originally collected by George Dreher and Ronald Ash for the purpose of studying gender differences in mentoring. The results of that study are reported in Dreher and Ash (1990). The data set was collected in 1988 through a mail survey of 1,000 graduates from the MBA and undergraduate classes of 1978 and 1983 . The sample was drawn to generate an approximately equal number of graduates by school, year, gender, and degree. 440 survey forms were returned. ${ }^{1}$ For purposes of the current study we did not include the 48 respondents who reported working part-time (less than 35 hours per week) or the 28 individuals who were self-employed. Of the remaining 364 responses, there are 312 usable observations. There are 168 men and 144 women in the sample.

Given the population surveyed, several sources of variation in pay are eliminated (or reduced) in the data set. Variances in quantity and quality of education, length of work experience, and occupation are greatly constrained. Since only the graduates from

\footnotetext{
122 of the surveys were returned because of wrong addresses. The response rate, therefore, was $45 \%$, which is similar to response rates in other surveys that use similar methodologies.
} 
1978 and 1983 were sampled, the data set is restricted to a fairly well-defined age/experience cohort. The average age of those sampled is 32 , and $95 \%$ of the individuals are between 26 and 40 years old.

The data set includes an extensive set of measures of human capital, firm, occupation, and individual characteristics. Also, the respondents to the survey were asked to report the total annual pay they received and to disaggregate their total pay between base pay and contingent pay. ${ }^{2}$

Below is a description of the variables used in our analysis. The discussion of the variables is divided into measures of pay, human capital, job and firm characteristics, and individual characteristics. Variable definitions and sample means, by gender, are summarized in Table 1.

Measures of pay. The means in Table 1 show that there is a large and statistically significant difference in pay between men and women in this sample. The mean pay for men is $\$ 59,597$, and the mean for women is $\$ 45,044$. Although this ratio of female to male pay, .76, may seem small given the narrow population sampled, it is consistent with recent survey data of the gender-pay ratio in professional occupations. Bureau of Labor Statistics figures for 1988 indicate that the median weekly earnings of female professionals and managers was $70 \%$ of the median weekly earnings of men. The ratio in sales and technical occupations was $65 \%$.

The base pay ratio in this sample is 87 . Of the $\$ 14,553$ gap in total pay, $\$ 6,100$ is due to the difference in base pay. The contingent pay ratio is only .31. Of the gap in total pay, $\$ 8,467$ is due to the difference in contingent pay. Despite the fact that contingent pay is a relatively small portion of total pay, $12 \%$ for men and $6 \%$ for women, the difference in contingent pay between

\footnotetext{
${ }^{2}$ The survey asked respondents to report total direct earnings from the employer, excluding non-cash benefits, and also to report the components of total earnings, including annual salary, annual income from commissions, and supplementary income such as bonuses and profit sharing. Our measure of contingent pay is the sum of the reported commissions and supplementary income.
}

men and women accounts for $58 \%$ of the difference in total pay. These raw data suggest that there may be important differences between the ways in which base pay and contingent pay contribute to the differential in total pay.

Human capital. The data set contains one measure of formal education and several measures of work experience. Sampling only business school graduates simplifies the measure of education: DEGREE is a dummy variable indicating whether or not the respondent has a graduate degree in business. The measures of work experience include EXP, the total number of years of actual work experience, YRs, the number of years of work experience since graduation from business school, and TENURE, the number of years with the current employer.

Four additional measures of work experience help qualify the more standard measures listed above. INTERRUPTIONS is the total number of months since graduation during which the respondent was not employed. JOB CHANGES is the number of times the respondent changed firms since graduation from business school. JOBS REJECTED is the number of job offers (including withinfirm transfers or promotions) since graduation that the individual rejected because the offer was not compatible with family or spouse needs. This variable is included to control for the possibility that women accept lower rates of return on their human capital in order to "follow their husbands." The means of this variables indicate, however, that women in this sample rejected fewer jobs for family-related reasons than did the men in the sample. This result may indicate that men had more jobs to reject, that a higher percentage of the men in the sample than of the women are married, or that married women in this age cohort are no longer following their husbands. ${ }^{3}$

\footnotetext{
${ }^{3}$ This difference between men and women in the number of jobs rejected for family-related reasons also holds by marital status. The mean number of jobs rejected for family reasons by married women in the sample is .46, whereas the mean for married men is .72. For single women and single men, the means are .17 and .5 , respectively.
} 
Table 1. Variable Definitions and Means of a Sample of 312 Business School Graduates from Two Large State Universities. (Standard Deviations in Parentheses)

\begin{tabular}{|c|c|c|c|}
\hline Variable & Definition & Men & Women \\
\hline TOTAL PAY & $=$ total annual job earnings $(\$ \$)$ & $\begin{array}{r}59596 \\
(44445)\end{array}$ & $\begin{array}{r}45044^{* *} \\
(21848)\end{array}$ \\
\hline BASE PAY & $=$ annual base pay $(\$ \$)$ & $\begin{array}{r}47309 \\
(22587)\end{array}$ & $\begin{array}{r}41210^{* *} \\
(17261)\end{array}$ \\
\hline CONTINGENT PAY & $=$ annual pay that was contingent on job performance $(\$ \$)$ & $\begin{array}{r}12286 \\
(37586)\end{array}$ & $\begin{array}{r}3819 * * \\
(6922)\end{array}$ \\
\hline DEGREE & $=1$ for master's degree and 0 for bachelor's degree & $\begin{array}{l}.649 \\
(.479)\end{array}$ & $\begin{array}{l}.514^{*} \\
(.502)\end{array}$ \\
\hline EXP & $=$ total years of work experience & $\begin{array}{l}10.185 \\
(3.999)\end{array}$ & $\begin{array}{c}9.465 \\
(4.090)\end{array}$ \\
\hline YRS & $=$ years of work experience since graduation & $\begin{array}{l}7.929 \\
(2.650)\end{array}$ & $\begin{array}{c}7.340 \\
(2.600)\end{array}$ \\
\hline TENURE & $=$ years with current employer & $\begin{array}{l}5.292 \\
(3.720)\end{array}$ & $\begin{array}{c}4.819 \\
(3.870)\end{array}$ \\
\hline INTERRUPTIONS & $=$ number of months out of the work force since graduation & $\begin{array}{l}1.774 \\
(3.989)\end{array}$ & $\begin{array}{c}2.771 \\
(5.673)\end{array}$ \\
\hline MENTOR & $=$ amount of mentoring received between 0 and 5 & $\begin{array}{l}2.922 \\
(.770)\end{array}$ & $\begin{array}{l}3.006 \\
(.855)\end{array}$ \\
\hline JOB CHANGES & $=$ number of job (firm) changes since graduation & $\begin{array}{l}1.375 \\
(1.503)\end{array}$ & $\begin{array}{c}1.472 \\
(1.496)\end{array}$ \\
\hline JOBS REJECTED & $=$ number of jobs rejected for family-related reasons & $\begin{array}{c}.655 \\
(1.309)\end{array}$ & $\begin{array}{l}.354 \\
(.642)\end{array}$ \\
\hline FIRM SIZE & $=0$ for less than 50 employees $\ldots 7$ for more than 50,000 & $\begin{array}{c}4.179 \\
(2.309)\end{array}$ & $\begin{array}{c}4.229 \\
(2.317)\end{array}$ \\
\hline INDUSTRY & $=1$ for manufacturing; 0 otherwise & $\begin{array}{l}.268 \\
(.444)\end{array}$ & $\begin{array}{l}.181 \\
(.386)\end{array}$ \\
\hline PROFESSIONAL & $=1$ for professional occupation; 0 otherwise & $\begin{array}{l}.393 \\
(.490)\end{array}$ & $\begin{array}{l}.486 \\
(.502)\end{array}$ \\
\hline TECHNICAL & $=1$ for technical occupation; 0 otherwise & $\begin{array}{l}.071 \\
(.258)\end{array}$ & $\begin{array}{l}.035 \\
(.184)\end{array}$ \\
\hline SALES & $=1$ for sales occupation; 0 otherwise & $\begin{array}{l}.196 \\
(.398)\end{array}$ & $\begin{array}{l}.215 \\
(.412)\end{array}$ \\
\hline HOURS & = average weekly hours & $\begin{array}{l}50.804 \\
(8.377)\end{array}$ & $\begin{array}{l}47.938^{*} \\
(6.444)\end{array}$ \\
\hline MARITAL & $=1$ if married; 0 otherwise & $\begin{array}{l}.750 \\
(.434)\end{array}$ & $\begin{array}{l}.604^{*} \\
(.491)\end{array}$ \\
\hline DEPENDENTS & $=$ number of dependents & $\begin{array}{c}.857 \\
(1.011)\end{array}$ & $\begin{aligned} .444^{*} \\
(.834)\end{aligned}$ \\
\hline FAMILY TIME & $=\%$ of time spent with family & $\begin{array}{c}25.827 \\
(13.795)\end{array}$ & $\begin{array}{c}26.611 \\
(16.492)\end{array}$ \\
\hline SUPERVISION & $=$ number of supervisors reporting to the respondent & $\begin{array}{c}.976 \\
(1.209)\end{array}$ & $\begin{array}{r}.340^{*} \\
(.681)\end{array}$ \\
\hline PROMOTIONS & $=$ number of promotions received since graduating & $\begin{array}{c}3.494 \\
(2.235)\end{array}$ & $\begin{array}{c}3.278 \\
(1.815)\end{array}$ \\
\hline \% CONTINGENT & $=$ contingent pay $/$ total pay & $\begin{array}{l}.125 \\
(.179)\end{array}$ & $\begin{array}{l}.062 * \\
(.086)\end{array}$ \\
\hline $\mathrm{n}$ & & 168 & 144 \\
\hline
\end{tabular}

*Significant difference in means between men and women at the .05 level; **at the .01 level. 
Finally, the data set includes a measure of the intensity and quality of mentoring received by the respondent (MENTOR). Respondents indicated the extent to which they had experienced various forms of mentoring from formally designated mentors, sponsors, or influential managers since their graduation from business school. MENTOR ranges between 1 and 5 , and is the average score on 18 items on a mentoring scale used in the survey. ${ }^{4}$ Since mentors usually aid subordinates with career development, involve them in networking, and provide them with information about the firm, including mentoring in the analysis should augment the measure of firm tenure as a proxy for the amount of firmspecific training the individual has received.

Job and firm characteristics. There are several variables relating to the individual's occupation, job, and firm. FIRM SIZE is a measure of the number of employees in the respondent's firm. ${ }^{5}$ INDUSTRY is a dummy variable indicating whether the firm is in a manufacturing industry. HOURS is the average weekly hours of work. PROFESSIONAL, TECHNICAL, and SALES are occupation dummies. The excluded occupation is managerial. These occupation variables constitute relatively narrow occupational categories, reflecting the fact that the population includes only business school graduates.

\footnotetext{
${ }^{4} \mathrm{~A}$ global measure of mentoring practices was developed in Dreher and Ash (1990) by selecting items used in previous research (Noe 1988; Whitely et al. 1988). The items were selected to cover the various career and psychological functions described by Kram (1985). When answering these questions, respondents were asked to "consider your career history since graduating from [your] program and the degree to which influential managers have served as your sponsor or mentor (this need not be limited to one person)." The response format ranged from a low of " $1=$ not at all" to a high of " $5=$ to a very large extent." the internal consistency (coefficient alpha) for the scale was .95. See Dreher and Ash (1990) for a more complete discussion of the mentoring variable and for a list of the 18 mentoring items used to calculate the measure.

${ }^{5}$ FIRM SIZE is coded as zero for $1-49$ employees; 1 for $50-99$; 2 for $100-499$; 3 for $500-999$; 4 for $1,000-$ 4,$999 ; 5$ for $5,000-9,999 ; 6$ for $10,000-49,999$; and 7 for $50,000+$ employees.
}

The data set includes two other measures that help to control for the level of the individual's job in the firm's hierarchy. SUPERVISION is a measure of supervisory responsibilities, indicating the number of supervisors who report to the respondent. It is coded 0 if no supervisors report to the individual; 1 if $1-2$ supervisors report; 2 if $3-5$ report; 3 if 6-8 report; and 4 if 9 or more report. PROMOTIONS is the total number of promotions the individual has received since graduation. Although these variables may be closely related to the human capital measures and may proxy for job productivity, differences in supervisory responsibilities and promotions may also be the result of discrimination that limits the upward mobility of women. We have included these two measures in our discussion of job characteristics because they clearly proxy for mobility and the individual's level in the job hierarchy, regardless of whether job level is the result of discrimination or productivity. As explained in the previous section, we are interested in controlling for job level even if job level may be determined partly by discrimination.

Individual characteristics. This data set contains information about marital status and number of dependents. These measures are traditionally included in analyses of the gender-pay gap. The data set also includes a measure of the time each individual spends with his or her family. The survey asked respondents to indicate what percentage of the total amount of time spent on work, recreation, and family activities was devoted to their family (FAMILY TIME). One reason for the gender-pay gap may be that women have more family responsibilities than men and, therefore, lower levels of effort available for job activities (Becker 1985). The average of FAMILY TIME is one percentage point higher for the women in the sample than for the men, but the difference is not statistically significant. As mentioned above, Hersch (1991) included controls for household responsibilities and found that the reduction in the unexplained portion of the pay gap attributable to these factors was very small. 


\section{Empirical Models}

For total pay and base pay, we estimate separately for men and women the equation

$$
\ln \left(\mathrm{PAY}_{\mathrm{i}}\right)=B_{1} X_{i}+e_{i},
$$

where $\ln$ (PAY) is the natural log of the pay variable, $B$ is a vector of coefficients, and $X$ is a vector of the human capital, job, and individual characteristics described above.

We use the Blinder (1973) method for decomposing the pay gap for the measures of total pay and base pay in this sample. This is the standard method used for decomposing the pay gap between the portion of the gap due to differences between men and women in their endowments (means) of the explanatory variables and the portion due to differences in the rates of return (coefficients) to those endowments.

The measure of contingent pay, however, does not allow us to use a comparable method of analysis of the gap for this form of pay. Contingent pay is censored at a lower bound of zero. Although individuals can earn positive pay awards by achieving or exceeding specific performance standards, compensation policies generally do not specify that the individual must return pay for failing to meet the performance standard. In this sample of 312 observations, the contingent pay variable has a value of zero in 132 cases: 59 out of 168 cases for men and in 73 out of 144 cases for women.

Because of this censoring of the contingent pay variable, we estimate the gender difference in contingent pay with a standard tobit model, using a dummy variable for gender. Since contingent pay is zero in a large number of cases, we do not take the normal log transformation of the pay variable. The focus of our analysis, therefore, is on total pay and base pay, and on how the unexplained portion of the pay gap differs between total and base pay. A tobit model of contingent pay is estimated simply to test whether or not the difference in contingent pay, holding other things equal, between men and women in this sample is statistically significant.

The tobit model of contingent pay is specified as

$$
\begin{gathered}
\mathrm{PAY}_{i}^{*}=B_{1} X_{i}+b_{2}(\text { GENDER })+v_{i} \\
\mathrm{PAY}_{i}=\mathrm{PAY}_{i}^{*} \text { if } \mathrm{PAY}_{i}^{*}>0 \\
=0 \text { if } \mathrm{PAY}_{i}^{*} \leq 0,
\end{gathered}
$$

where $\mathrm{PAY}_{i}^{*}$ is the value of contingent pay earned, $\mathrm{PAY}_{i}$ is the observed level of contingent pay, and GENDER is a dummy variable equal to 0 for women and 1 for men. Under the assumption that $v_{i}$ is distributed $\mathrm{N}\left(0, \sigma^{2}\right)$, we estimate the coefficients by maximizing a tobit likelihood function.

\section{OLS Results and Decomposition of the Differential in Total Pay and Base Pay}

OLS estimates of model (1) are presented in Tables 2 and 3 . Table 2 reports the results for the estimates of the total pay model, and the results for base pay are reported in Table 3 . We first estimated the equations without the SUPERVISION and PROMOTIONS variables. In both tables, these results are reported in columns (1) and (2) for men and women, respectively. Results for estimates including SUPERVISION and PROMOTIONS are reported in columns (3) and (4).

Of the experience and tenure variables, only years since graduation (YRS) is significant. Including quadratic terms for the experience and tenure variables did not change the results, and the quadratic terms were not significant. These results may be due to the limited range of experience in the sample. They may also be due to the other experience-related variables included in the equation. Interruptions in work experience have a significant negative effect on both total pay and base pay. Except for the effect of the number of jobs rejected for family reasons, the coefficients on the human capital variables are in the expected direction. The coefficients on JOBS REJECTED are positive for both men and women, but insignificant. This finding may indicate 
Table 2. Factors Affecting Total Pay:

OLS Results for $\ln$ (TOTAL PAY). (Standard Errors in Parentheses)

\begin{tabular}{|c|c|c|c|c|}
\hline Variable & $\begin{array}{c}\text { (1) } \\
\text { Men }\end{array}$ & $\begin{array}{c}\text { (2) } \\
\text { Women }\end{array}$ & $\begin{array}{c}\text { (3) } \\
\text { Men }\end{array}$ & $\begin{array}{c}\text { (4) } \\
\text { Women }\end{array}$ \\
\hline DEGREE & $\begin{array}{l}.209 * * \\
(.074)\end{array}$ & $\begin{array}{l}.200 * * \\
(.058)\end{array}$ & $\begin{array}{l}.210^{* *} \\
(.073)\end{array}$ & $\begin{array}{l}.207 * * \\
(.057)\end{array}$ \\
\hline EXP & $\begin{array}{l}.0001 \\
(.011)\end{array}$ & $\begin{array}{c}.012 \\
(.009)\end{array}$ & $\begin{array}{l}.002 \\
(.011)\end{array}$ & $\begin{array}{l}.014 \\
(.009)\end{array}$ \\
\hline YRS & $\begin{array}{l}.059 * * \\
(.016)\end{array}$ & $\begin{array}{l}.053^{* *} \\
(.013)\end{array}$ & $\begin{array}{l}.046^{* *} \\
(.017)\end{array}$ & $\begin{array}{l}.039 * * \\
(.014)\end{array}$ \\
\hline TENURE & $\begin{array}{c}-.005 \\
(.014)\end{array}$ & $\begin{array}{l}.005 \\
(.009)\end{array}$ & $\begin{array}{l}-.006 \\
(.013)\end{array}$ & $\begin{array}{l}.009 \\
(.009)\end{array}$ \\
\hline INTERRUPTIONS & $\begin{array}{c}-.019 * \\
(.009)\end{array}$ & $\begin{array}{c}-.010^{*} \\
(.005)\end{array}$ & $\begin{array}{l}-.017 \\
(.009)\end{array}$ & $\begin{array}{l}-.008 \\
(.005)\end{array}$ \\
\hline MENTOR & $\begin{array}{l}.066 \\
(.045)\end{array}$ & $\begin{array}{l}.053^{*} \\
(.031)\end{array}$ & $\begin{array}{l}.047 \\
(.045)\end{array}$ & $\begin{array}{l}.034 \\
(.032)\end{array}$ \\
\hline JOB CHANGES & $\begin{array}{l}-.045 \\
(.033)\end{array}$ & $\begin{array}{l}-.012 \\
(.023)\end{array}$ & $\begin{array}{l}-.044 \\
(.033)\end{array}$ & $\begin{array}{l}-.018 \\
(.023)\end{array}$ \\
\hline JOBS REJECTED & $\begin{array}{l}.040 \\
(.027)\end{array}$ & $\begin{array}{c}.028 \\
(.041)\end{array}$ & $\begin{array}{c}.035 \\
(.026)\end{array}$ & $\begin{array}{c}.031 \\
(.040)\end{array}$ \\
\hline FIRM SIZE & $\begin{array}{l}.009 \\
(.016)\end{array}$ & $\begin{array}{l}.037 * * \\
(.013)\end{array}$ & $\begin{array}{c}.012 \\
(.016)\end{array}$ & $\begin{array}{l}.035 * * \\
(.012)\end{array}$ \\
\hline INDUSTRY & $\begin{array}{l}-.040 \\
(.077)\end{array}$ & $\begin{array}{c}-.028 \\
(.067)\end{array}$ & $\begin{array}{l}-.070 \\
(.077)\end{array}$ & $\begin{array}{l}-.026 \\
(.065)\end{array}$ \\
\hline PROFESSIONAL & $\begin{array}{l}-.026 \\
(.079)\end{array}$ & $\begin{array}{l}.025 \\
(.067)\end{array}$ & $\begin{array}{c}.029 \\
(.080)\end{array}$ & $\begin{array}{l}.059 \\
(.067)\end{array}$ \\
\hline TECHNICAL & $\begin{array}{c}-.093 \\
(.138)\end{array}$ & $\begin{array}{l}.249 \\
(.161)\end{array}$ & $\begin{array}{l}-.037 \\
(.139)\end{array}$ & $\begin{array}{l}.219 \\
(.159)\end{array}$ \\
\hline SALES & $\begin{array}{l}.123 \\
(.094)\end{array}$ & $\begin{array}{l}.118 \\
(.079)\end{array}$ & $\begin{array}{l}.187 \\
(.097)\end{array}$ & $\begin{array}{l}.145 \\
(.079)\end{array}$ \\
\hline HOURS & $\begin{array}{l}.015^{* *} \\
(.004)\end{array}$ & $\begin{array}{l}.015^{* *} \\
(.005)\end{array}$ & $\begin{array}{l}.012 * * \\
(.004)\end{array}$ & $\begin{array}{l}.012 * \\
(.005)\end{array}$ \\
\hline MARITAL & $\begin{array}{l}.104 \\
(.099)\end{array}$ & $\begin{array}{l}.027 \\
(.062)\end{array}$ & $\begin{array}{l}.134 \\
(.099)\end{array}$ & $\begin{array}{l}.053 \\
(.061)\end{array}$ \\
\hline DEPENDENTS & $\begin{array}{c}.011 \\
(.040)\end{array}$ & $\begin{array}{c}-.005 \\
(.037)\end{array}$ & $\begin{array}{c}.005 \\
(.040)\end{array}$ & $\begin{array}{l}-.010 \\
(.038)\end{array}$ \\
\hline FAMILY TIME & $\begin{array}{l}.002 \\
(.003)\end{array}$ & $\begin{array}{l}-.003 \\
(.002)\end{array}$ & $\begin{array}{c}.001 \\
(.003)\end{array}$ & $\begin{array}{l}-.003 \\
(.002)\end{array}$ \\
\hline SUPERVISION & - & - & $\begin{array}{l}.060 \\
(.032)\end{array}$ & $\begin{array}{l}.059 \\
(.041)\end{array}$ \\
\hline PROMOTIONS & - & - & $\begin{array}{l}.027 \\
(.017)\end{array}$ & $\begin{array}{c}.040^{*} \\
(.017)\end{array}$ \\
\hline CONSTANT & $\begin{array}{l}9.181 * * \\
(.309)\end{array}$ & $\begin{array}{l}8.966^{* *} \\
(.261)\end{array}$ & $\begin{array}{l}9.239 * * \\
(.306)\end{array}$ & $\begin{array}{c}9.027^{* *} \\
(.260)\end{array}$ \\
\hline $\mathbf{R}^{2}$ & .349 & .580 & .379 & .604 \\
\hline Adj. $R^{2}$ & .275 & .523 & .299 & .543 \\
\hline SEE & .413 & .294 & .406 & .288 \\
\hline $\mathbf{n}$ & 168 & 144 & 168 & 144 \\
\hline
\end{tabular}

*Statistically significant at the .05 level; **at the .01 level (2-tailed tests). that JOBS REJECTED is measuring job mobility (more offers to move) rather than job immobility due to family ties.

The results on the individual characteristics are consistent with findings of other studies. The coefficients on marital status are positive in each specification, and in each case the coefficient for men is larger than that for women. In most of the specifications the coefficient on the family-time variable is positive but insignificant for men. The results are negative and significant for women in the total pay equation that includes SUPERVISION and PROMOTIONS, and negative and significant for women in both base pay equations.

The coefficients on the SUPERVISION and PROMOTION variables are positive for men and women in both the total pay and base pay equations. The coefficients on the PROMOTION variable are significant in each case. The coefficients on the SUPERVISION variable are significant at the $10 \%$ level for men and not quite significant for women.

Despite the fact that the data set is small and was drawn from a relatively narrow segment of the work force, the results are consistent, more or less, with expectations based on previous studies. Furthermore, the results for the total pay model are very similar to those for the base pay model.

Following Blinder (1973), we decompose the estimated pay gap into the effects of differences in means and differences in coefficients. We calculate and report the unadjusted pay ratio and the adjusted pay ratio. The adjusted pay ratio is calculated using the expected female pay evaluated at the male means of the independent variables. We also calculate the percentage of the gap attributable to differences in means, and the percentage of the gap attributable to differences in coefficients. ${ }^{6}$ The per-

\footnotetext{
${ }^{6}$ See Cain (1986) and Blau and Ferber (1987) for a careful discussion of this decomposition method and a review of the discrimination literature in which this analysis has been applied.

The expected pay gap between men and women based on the regression results is calculated as

Pay gap $=\Sigma B_{i m}\left(\bar{X}_{i m}-\bar{X}_{i f}\right)+\Sigma \bar{X}_{i f}\left(B_{i m}-B_{i f}\right)$, where $B_{i}$ is the estimated coefficient for the $i t h$ variable and $\bar{X}_{i}$ is the mean of the $i t h$ variable from the OLS estimates reported in Tables 2 and 3. The $f$ and
} 
centage of the gap due to coefficients is the "unexplained" portion of the pay gap. If the estimated models of pay have fully controlled for productivity factors, then this unexplained percentage of the gap is a measure of discrimination. As mentioned above, the unexplained portion of the pay gap is a lower bound estimate of the effects of discrimination when endogenous variables that have likely been affected by wage discrimination are used in the analysis.

The results of the decomposition for both the total pay and base pay models are reported in Table 5. The values from the decomposition have been calculated using both the male coefficients and the female coefficients. Results using the female coefficients are reported in parentheses below the values based on the male coefficients.

According to the results in Table 5, there is a large difference in the unexplained gap in pay between the total pay and base pay models. When human capital, firm, occupation, and individual characteristics are included in the estimate of total pay, the pay ratio, adjusted for differences in means, is .88. When controls for supervisory responsibilities and number of promotions are included, the adjusted ratio increases to .91 . The percentage of the gap in total pay that is attributable to differences in coefficients is $44 \%$ and $34 \%$ in those respective specifications. Given the narrow sample used and the number of controls in the equation, including controls for occupation, supervisory responsibilities, and promotions, a 9-12\% gap in pay that is attributable to differences in coefficients is large and represents a significant economic

$m$ subscripts denote the female and male equations, respectively. The first term in the equation is the difference in pay due to differences between the male and female means, and the second term is the difference in pay due to differences between the male and female coefficients. Cain (1986) showed that the decomposed values depend on the choice of whether the male coefficients or the female coefficients are used as the basis of the decomposition. Based on the assumption that the male equation represents the prevailing rate at which endowments would be compensated if market discrimination were eliminated, it is the convention to decompose the pay gap using the male coefficients.
Table 3. Factors Affecting Base Pay:

OLS Results for $\ln$ (BASE PAY). (Standard Errors in Parentheses)

\begin{tabular}{|c|c|c|c|c|}
\hline & (1) & (2) & (3) & (4) \\
\hline Variable & Men & Women & Men & Women \\
\hline DEGREE & $\begin{array}{l}.195 * * \\
(.065)\end{array}$ & $\begin{array}{l}.211 * * \\
(.052)\end{array}$ & $\begin{array}{l}.201 * * \\
(.062)\end{array}$ & $\begin{array}{c}.215 * * \\
(.051)\end{array}$ \\
\hline EXP & $\begin{array}{c}.008 \\
(.010)\end{array}$ & $\begin{array}{l}.012 \\
(.008)\end{array}$ & $\begin{array}{c}.011 \\
(.009)\end{array}$ & $\begin{array}{l}.014 \\
(.008)\end{array}$ \\
\hline YRS & $\begin{array}{l}.046^{* * *} \\
(.014)\end{array}$ & $\begin{array}{l}.050 * * \\
(.012)\end{array}$ & $\begin{array}{l}.026 \\
(.014)\end{array}$ & $\begin{array}{l}.035^{* *} \\
(.013)\end{array}$ \\
\hline TENURE & $\begin{array}{c}-.002 \\
(.012)\end{array}$ & $\begin{array}{c}.0004 \\
(.0084)\end{array}$ & $\begin{array}{c}-.003 \\
(.011)\end{array}$ & $\begin{array}{l}.005 \\
(.008)\end{array}$ \\
\hline INTERRUPTIONS & $\begin{array}{c}-.017 * \\
(.008)\end{array}$ & $\begin{array}{c}-.009 * \\
(.004)\end{array}$ & $\begin{array}{c}-.013 \\
(.008)\end{array}$ & $\begin{array}{c}-.007 \\
(.004)\end{array}$ \\
\hline MENTOR & $\begin{array}{c}.024 \\
(.039)\end{array}$ & $\begin{array}{c}.031 \\
(.028)\end{array}$ & $\begin{array}{l}-.003 \\
(.038)\end{array}$ & $\begin{array}{c}.011 \\
(.028)\end{array}$ \\
\hline JOB CHANGES & $\begin{array}{c}-.066^{*} \\
(.029)\end{array}$ & $\begin{array}{c}-.018 \\
(.021)\end{array}$ & $\begin{array}{c}-.066^{*} \\
(.028)\end{array}$ & $\begin{array}{l}-.023 \\
(.020)\end{array}$ \\
\hline JOBS REJECTED & $\begin{array}{c}.024 \\
(.023)\end{array}$ & $\begin{array}{c}.033 \\
(.037)\end{array}$ & $\begin{array}{c}.017 \\
(.022)\end{array}$ & $\begin{array}{l}.036 \\
(.036)\end{array}$ \\
\hline FIRM SIZE & $\begin{array}{l}.003 \\
(.014)\end{array}$ & $\begin{array}{l}.033^{* *} \\
(.011)\end{array}$ & $\begin{array}{c}.007 \\
(.013)\end{array}$ & $\begin{array}{l}.031 * * \\
(.011)\end{array}$ \\
\hline INDUSTRY & $\begin{array}{c}.069 \\
(.068)\end{array}$ & $\begin{array}{c}-.043 \\
(.060)\end{array}$ & $\begin{array}{l}.025 \\
(.066)\end{array}$ & $\begin{array}{c}-.041 \\
(.058)\end{array}$ \\
\hline PROFESSIONAL & $\begin{array}{c}.027 \\
(.069)\end{array}$ & $\begin{array}{c}.009 \\
(.060)\end{array}$ & $\begin{array}{c}.089 \\
(.069)\end{array}$ & $\begin{array}{c}.042 \\
(.060)\end{array}$ \\
\hline TECHNICAL & $\begin{array}{c}.035 \\
(.121)\end{array}$ & $\begin{array}{c}.253 \\
(.144)\end{array}$ & $\begin{array}{c}.088 \\
(.118)\end{array}$ & $\begin{array}{c}.216 \\
(.142)\end{array}$ \\
\hline SALES & $\begin{array}{c}-.036 \\
(.083)\end{array}$ & $\begin{array}{c}.045 \\
(.071)\end{array}$ & $\begin{array}{c}.028 \\
(.083)\end{array}$ & $\begin{array}{c}.067 \\
(.070)\end{array}$ \\
\hline HOURS & $\begin{array}{l}.014 * * \\
(.004)\end{array}$ & $\begin{array}{l}.013 * * \\
(.004)\end{array}$ & $\begin{array}{l}.011 * * \\
(.004)\end{array}$ & $\begin{array}{c}.010^{*} \\
(.004)\end{array}$ \\
\hline MARITAL & $\begin{array}{c}.101 \\
(.087)\end{array}$ & $\begin{array}{c}.020 \\
(.056)\end{array}$ & $\begin{array}{c}.148 \\
(.084)\end{array}$ & $\begin{array}{l}.045 \\
(.055)\end{array}$ \\
\hline DEPENDENTS & $\begin{array}{c}-.033 \\
(.036)\end{array}$ & $\begin{array}{c}-.003 \\
(.033)\end{array}$ & $\begin{array}{c}-.045 \\
(.034)\end{array}$ & $\begin{array}{c}-.004 \\
(.034)\end{array}$ \\
\hline FAMILY TIME & $\begin{array}{c}.0002 \\
(.0026)\end{array}$ & $\begin{array}{c}-.003 \\
(.002)\end{array}$ & $\begin{array}{c}-.0005 \\
(.0025)\end{array}$ & $\begin{array}{c}-.004^{*} \\
(.002)\end{array}$ \\
\hline SUPERVISION & - & - & $\begin{array}{c}.052 \\
(.027)\end{array}$ & $\begin{array}{c}.048 \\
(.036)\end{array}$ \\
\hline PROMOTIONS & - & - & $\begin{array}{l}.046^{* * *} \\
(.014)\end{array}$ & $\begin{array}{l}.043 * * \\
(.015)\end{array}$ \\
\hline CONSTANT & $\begin{array}{l}9.352^{* *} \\
(.271)\end{array}$ & $\begin{array}{l}9.177^{* *} \\
(.234)\end{array}$ & $\begin{array}{l}9.390 * * \\
(.261)\end{array}$ & $\begin{array}{c}9.251 * * \\
(.231)\end{array}$ \\
\hline $\mathbf{R}^{2}$ & .347 & .579 & .412 & .609 \\
\hline $\operatorname{Adj} . R^{2}$ & .273 & .523 & .336 & .550 \\
\hline SEE & .362 & .264 & .346 & .257 \\
\hline $\mathbf{n}$ & 168 & 144 & 168 & 144 \\
\hline
\end{tabular}

*Statistically significant at the .05 level; **at the .01 level (2-tailed tests). 
Table 4. OLS Results for $\ln$ (тотаL Pay), Controlling for the Percentage of Contingent Pay. (Standard Errors in Parentheses)

\begin{tabular}{|c|c|c|c|c|c|}
\hline Variable & Men & Women & Variable & Men & Women \\
\hline DEGREE & $\begin{array}{l}.189 * * \\
(.057)\end{array}$ & $\begin{array}{l}.217 * * \\
(.050)\end{array}$ & SALES & $\begin{array}{l}-.009 \\
(.078)\end{array}$ & $\begin{array}{c}.029 \\
(.072)\end{array}$ \\
\hline EXP & $\begin{array}{l}.007 \\
(.008)\end{array}$ & $\begin{array}{c}.013 \\
(.008)\end{array}$ & HOURS & $\begin{array}{l}.011^{* *} \\
(.003)\end{array}$ & $\begin{array}{l}.008 * \\
(.004)\end{array}$ \\
\hline YRS & $\begin{array}{l}.031 * \\
(.013)\end{array}$ & $\begin{array}{l}.032 * \\
(.013)\end{array}$ & MARITAL & $\begin{array}{c}.166^{*} \\
(.077)\end{array}$ & $\begin{array}{l}.049 \\
(.054)\end{array}$ \\
\hline TENURE & $\begin{array}{l}.001 \\
(.011)\end{array}$ & $\begin{array}{l}.003 \\
(.008)\end{array}$ & DEPENDENTS & $\begin{array}{l}-.037 \\
(.032)\end{array}$ & $\begin{array}{l}-.002 \\
(.033)\end{array}$ \\
\hline INTERRUPTIONS & $\begin{array}{l}-.013 \\
(.007)\end{array}$ & $\begin{array}{l}-.006 \\
(.004)\end{array}$ & FAMILY TIME & $\begin{array}{l}-.0003 \\
(.0023)\end{array}$ & $\begin{array}{c}-.004^{*} \\
(.002)\end{array}$ \\
\hline MENTOR & $\begin{array}{l}.008 \\
(.035)\end{array}$ & $\begin{array}{l}-.003 \\
(.029)\end{array}$ & SUPERVISION & $\begin{array}{l}.043 \\
(.025)\end{array}$ & $\begin{array}{l}.041 \\
(.036)\end{array}$ \\
\hline JOB CHANGES & $\begin{array}{l}-.046 \\
(.026)\end{array}$ & $\begin{array}{l}-.027 \\
(.020)\end{array}$ & PROMOTIONS & $\begin{array}{l}.039 * * \\
(.013)\end{array}$ & $\begin{array}{l}.044^{* *} \\
(.015)\end{array}$ \\
\hline JOBS REJECTED & $\begin{array}{c}.013 \\
(.021)\end{array}$ & $\begin{array}{c}.037 \\
(.035)\end{array}$ & $\%$ CONTINGENT & $\begin{array}{l}1.511^{* *} \\
(.154)\end{array}$ & $\begin{array}{l}1.772 * * \\
(.284)\end{array}$ \\
\hline FIRM SIZE & $\begin{array}{l}.013 \\
(.012)\end{array}$ & $\begin{array}{l}.028^{*} \\
(.011)\end{array}$ & CONSTANT & $\begin{array}{l}9.346^{* *} \\
(.239)\end{array}$ & $\begin{array}{l}9.380 * * \\
(.234)\end{array}$ \\
\hline INDUSTRY & $\begin{array}{c}-.013 \\
(.060)\end{array}$ & $\begin{array}{l}-.049 \\
(.057)\end{array}$ & $\mathbf{R}^{2}$ & .624 & .699 \\
\hline PROFESSIONAL & $\begin{array}{l}.055 \\
(.063)\end{array}$ & $\begin{array}{l}.039 \\
(.059)\end{array}$ & Adj. $R^{2}$ & .573 & .650 \\
\hline TECHNICAL & $\begin{array}{l}.051 \\
(.109)\end{array}$ & $\begin{array}{c}.216 \\
(.139)\end{array}$ & $\begin{array}{l}\text { SEE } \\
\mathbf{n}\end{array}$ & $\begin{array}{l}.317 \\
168\end{array}$ & $\begin{array}{l}.252 \\
144\end{array}$ \\
\hline
\end{tabular}

*Statistically significant at the .05 level; **at the .01 level (2-tailed tests).

difference in pay. This finding, however, is very consistent with other studies of the gender-pay gap that carefully control for occupation or estimate the pay gap using occupation-specific data sets. Cain (1986), for example, listed four studies controlling for detailed occupations, and the adjusted pay ratios in those studies ranged from .86 to .93.

The decomposition of the results from the base pay models is very different. When SUPERVISION and PROMOTIONS are not included in the base pay regressions, the adjusted pay ratio is .98 , almost unity. Only $13 \%$ of the unadjusted pay gap is due to differences in coefficients. When SUPERVISION and PROMOTIONS are included in the estimates, the adjusted pay ratio is 1.0. As we pointed out above, this result does not mean that the estimate of discrimination in base pay is zero. At best, this is a lower bound estimate of discrimination in base pay, since we have controlled for variables that may be the result of discrimination. The values of SUPERVISION, PROMOTIONS, the occupation variables, MENTOR, TENURE, and possibly other variables may result from discrimination. In fact, given that differences in base pay are determined mostly by level of job in the hierarchy, we would expect a model of base pay that includes variables reflecting job level to explain the gender differences in base pay.

The most interesting result in Table 5 is the difference between the decompositions of the total pay and base pay estimates. Although the unexplained portion of the gap in base pay varies between zero and $2 \%$ in the two different specifications of the model, controlling for the same variables leaves a 9-12\% unexplained gap in total pay. Since the remaining $9 \%$ gap in total pay cannot be accounted for by the variables that account for all of the gender 
Table 5. Decomposition of Gender-Pay Differentials by Model and Type of Pay.

\begin{tabular}{|c|c|c|c|c|c|c|c|c|c|}
\hline \multirow{3}{*}{\multicolumn{2}{|c|}{ Model }} & \multicolumn{8}{|c|}{ Pay Ratio } \\
\hline & & \multicolumn{4}{|c|}{ Total Pay } & \multicolumn{4}{|c|}{ Base Pay } \\
\hline & & $\begin{array}{c}\text { Un- } \\
\text { adjusted }\end{array}$ & Adjusted $^{\mathrm{b}}$ & $\begin{array}{c}\text { Means }^{c} \\
(\%)\end{array}$ & $\begin{array}{c}\text { Coeff. } \\
(\%)\end{array}$ & $\begin{array}{c}\text { Un- } \\
\text { adjusted }\end{array}$ & Adjusted $^{\mathrm{b}}$ & $\begin{array}{c}\text { Means }^{c} \\
(\%)\end{array}$ & $\begin{array}{c}\text { Coeff. }^{\mathrm{d}} \\
(\%)\end{array}$ \\
\hline \multirow{2}{*}{ (1) } & HUMAN CAPITAL, & & & & & & & & \\
\hline & $\begin{array}{l}\text { FIRM/OCCUPATION, and } \\
\text { INDIVIDUAL CHARACTERISTICS }\end{array}$ & $\begin{array}{l}.77 \\
(.84)\end{array}$ & $\begin{array}{l}.88 \\
(51)\end{array}$ & $\begin{array}{c}56 \\
(49)\end{array}$ & 44 & $\begin{array}{l}.86 \\
(.98)\end{array}$ & $\begin{array}{l}.98 \\
(84)\end{array}$ & $\begin{array}{c}87 \\
(16)\end{array}$ & 13 \\
\hline \multirow{2}{*}{ (2) } & HUMAN CAPITAL, & & & & & & & & \\
\hline & $\begin{array}{l}\text { FIRM/OCCUPATION, INDIVIDUAL } \\
\text { CHARACTERISTICS, SUPERVISION, } \\
\text { and PROMOTION }\end{array}$ & $\begin{array}{l}.78 \\
(.91)\end{array}$ & $\begin{array}{c}.91 \\
(65)\end{array}$ & $\begin{array}{c}66 \\
(35)\end{array}$ & 34 & $\begin{array}{c}.87 \\
(1.01)\end{array}$ & $\begin{array}{c}1.00 \\
(108)\end{array}$ & $\begin{array}{l}103 \\
(-8)\end{array}$ & -3 \\
\hline \multirow{2}{*}{ (3) } & $\begin{array}{l}\text { HUMAN CAPITAL, } \\
\text { FIRM/OCCUPATION, INDIVIDUAL } \\
\text { CHARACTERISTICS, SUPERVISION, }\end{array}$ & & & & & & & & \\
\hline & $\begin{array}{l}\text { PROMOTION, and } \\
\% \text { CONTINGENT PAY }\end{array}$ & $\begin{array}{l}.78 \\
(1.01)\end{array}$ & $\begin{array}{c}.99 \\
(106)\end{array}$ & $\begin{array}{c}97 \\
(-6)\end{array}$ & 3 & - & - & - & - \\
\hline
\end{tabular}

Note: Male coefficients are used as the basis of the decomposition. Results using female coefficients are reported in parentheses.

${ }^{\text {a}}$ Model (1) is based on the results from equations (1) and (2) in Tables 2 and 3 for Total Pay and Base Pay, respectively. Model (2) is based on the results from equations (3) and (4), and model (3) is based on the results reported in Table 4.

bPay ratio after adjusting for differences in means of explanatory variables.

'Percentage of pay difference due to difference in means of explanatory variables.

dPercentage of pay difference due to difference in coefficients of explanatory variables.

difference in base pay, this $9 \%$ gap in total pay must be due to gender differences in contingent pay.

To test within the same analytic framework whether or not the remaining $9 \%$ gap in total pay is due to differences in contingent pay, we re-estimated the total pay model holding constant the proportion of total pay that was earned in the form of contingent pay (\%CONTINGENT). The regression results from this estimation are reported in Table 4. The results of the decomposition of these estimates are reported in the third row of results in Table 5 .

When \%CONTINGENT is included in the estimate of total pay, the adjusted pay ratio increases from .91 to .99 (Table 5). The results of this decomposition are very similar to the previous results from the base pay model. Controlling for contingent pay, there is basically no evidence of a gender gap in total pay. This finding is consistent with the hypothesis that the unexplained $9 \%$ gap in total pay, which we observe when controlling for human capital, job level, and other factors, is due to gender differences in contingent pay.

\section{Tobit Results}

Results from the estimates of the tobit model of contingent pay are presented in Table 6. Estimates of the level of contingent pay as the dependent variable are reported in columns (1) and (2), and estimates of contingent pay as a proportion of total pay are reported in columns (3) and (4). The gender pay difference is estimated here by including a GENDER dummy variable equal to 0 for women and 1 for men.

The coefficient on GENDER is positive and significant even when we control for job level variables. This result holds for both the level of contingent pay and contingent pay as a proportion of total pay. Although we cannot compare these results directly to the OLS estimates or decompose the tobit estimates, these results support the findings above that indicate a significant differ- 
Table 6. Tobit Coefficients for Contingent Pay Models.

(Standard Errors in Parentheses)

\begin{tabular}{|c|c|c|c|c|}
\hline \multirow[b]{2}{*}{ Variable } & \multicolumn{2}{|c|}{ Contingent Pay } & \multicolumn{2}{|c|}{$\begin{array}{c}\text { Contingent Pay/ } \\
\text { Total Pay }\end{array}$} \\
\hline & (1) & (2) & (3) & (4) \\
\hline DEGREE & $\begin{array}{c}6759 \\
(5422)\end{array}$ & $\begin{array}{c}6723 \\
(5422)\end{array}$ & $\begin{array}{l}.021 \\
(.027)\end{array}$ & $\begin{array}{l}.020 \\
(.027)\end{array}$ \\
\hline EXP & $\begin{array}{c}-385 \\
(867)\end{array}$ & $\begin{array}{c}-365 \\
(871)\end{array}$ & $\begin{array}{l}-.002 \\
(.004)\end{array}$ & $\begin{array}{l}-.002 \\
(.004)\end{array}$ \\
\hline YRS & $\begin{array}{c}2689 * \\
(1220)\end{array}$ & $\begin{array}{c}2649 * \\
(1321)\end{array}$ & $\begin{array}{c}.010 \\
(.006)\end{array}$ & $\begin{array}{l}.012 \\
(.007)\end{array}$ \\
\hline TENURE & $\begin{array}{l}-436 \\
(970)\end{array}$ & $\begin{array}{c}-482 \\
(976)\end{array}$ & $\begin{array}{l}-.002 \\
(.005)\end{array}$ & $\begin{array}{c}-.003 \\
(.005)\end{array}$ \\
\hline INTERRUPTIONS & $\begin{array}{c}-590 \\
(571)\end{array}$ & $\begin{array}{l}-585 \\
(575)\end{array}$ & $\begin{array}{l}-.004 \\
(.003)\end{array}$ & $\begin{array}{l}-.005 \\
(.003)\end{array}$ \\
\hline MENTOR & $\begin{array}{c}7141 * \\
(3149)\end{array}$ & $\begin{array}{c}7157 * \\
(3234)\end{array}$ & $\begin{array}{l}.039 * \\
(.016)\end{array}$ & $\begin{array}{l}.043^{* *} \\
(.016)\end{array}$ \\
\hline JOB CHANGES & $\begin{array}{c}-121 \\
(2380)\end{array}$ & $\begin{array}{c}-180 \\
(2381)\end{array}$ & $\begin{array}{l}.003 \\
(.012)\end{array}$ & $\begin{array}{l}.002 \\
(.012)\end{array}$ \\
\hline JOBS REJECTED & $\begin{array}{c}3294 \\
(2228)\end{array}$ & $\begin{array}{c}3244 \\
(2232)\end{array}$ & $\begin{array}{l}.019 \\
(.011)\end{array}$ & $\begin{array}{l}.020 \\
(.011)\end{array}$ \\
\hline FIRM SIZE & $\begin{array}{c}1063 \\
(1178)\end{array}$ & $\begin{array}{c}1120 \\
(1181)\end{array}$ & $\begin{array}{l}.003 \\
(.006)\end{array}$ & $\begin{array}{l}.003 \\
(.006)\end{array}$ \\
\hline INDUSTRY & $\begin{array}{l}-1242 \\
(5736)\end{array}$ & $\begin{array}{l}-1287 \\
(5782)\end{array}$ & $\begin{array}{l}-.004 \\
(.029)\end{array}$ & $\begin{array}{l}-.001 \\
(.029)\end{array}$ \\
\hline PROFESSIONAL & $\begin{array}{c}-3818 \\
(5995)\end{array}$ & $\begin{array}{c}-2991 \\
(6149)\end{array}$ & $\begin{array}{l}-.003 \\
(.030)\end{array}$ & $\begin{array}{c}.001 \\
(.031)\end{array}$ \\
\hline TECHNICAL & $\begin{array}{l}-15390 \\
(12602)\end{array}$ & $\begin{array}{l}-14284 \\
(12717)\end{array}$ & $\begin{array}{l}-.087 \\
(.064)\end{array}$ & $\begin{array}{l}-.078 \\
(.064)\end{array}$ \\
\hline SALES & $\begin{array}{l}12173 \\
(6677)\end{array}$ & $\begin{array}{l}13459 \\
(6959)\end{array}$ & $\begin{array}{l}.157 * * \\
(.034)\end{array}$ & $\begin{array}{l}.166^{* *} \\
(.035)\end{array}$ \\
\hline HOURS & $\begin{array}{c}660 \\
(335)\end{array}$ & $\begin{array}{c}580 \\
(356)\end{array}$ & $\begin{array}{c}.003 \\
(.002)\end{array}$ & $\begin{array}{l}.003 \\
(.002)\end{array}$ \\
\hline MARITAL & $\begin{array}{l}-2588 \\
(6393)\end{array}$ & $\begin{array}{l}-2386 \\
(6458)\end{array}$ & $\begin{array}{l}-.022 \\
(.032)\end{array}$ & $\begin{array}{l}-.025 \\
(.033)\end{array}$ \\
\hline DEPENDENTS & $\begin{array}{c}1899 \\
(3164)\end{array}$ & $\begin{array}{l}17587 \\
(3173)\end{array}$ & $\begin{array}{l}.025 \\
(.016)\end{array}$ & $\begin{array}{l}.024 \\
(.016)\end{array}$ \\
\hline FAMILY TIME & $\begin{array}{c}194 \\
(206)\end{array}$ & $\begin{array}{c}184 \\
(207)\end{array}$ & $\begin{array}{l}.001 \\
(.001)\end{array}$ & $\begin{array}{l}.001 \\
(.001)\end{array}$ \\
\hline SUPERVISION & - & $\begin{array}{c}1758 \\
(2627)\end{array}$ & - & $\begin{array}{l}.014 \\
(.013)\end{array}$ \\
\hline PROMOTIONS & - & $\begin{array}{c}-87 \\
(1349)\end{array}$ & - & $\begin{array}{l}-.007 \\
(.007)\end{array}$ \\
\hline GENDER & $\begin{array}{l}12826^{*} \\
(5200)\end{array}$ & $\begin{array}{l}12019 * \\
(5335)\end{array}$ & $\begin{array}{l}.083 * * \\
(.026)\end{array}$ & $\begin{array}{l}.077 * * \\
(.027)\end{array}$ \\
\hline Scale $^{a}$ & $\begin{array}{l}37095 \\
(2005)\end{array}$ & $\begin{array}{l}37086 \\
(2005)\end{array}$ & $\begin{array}{c}.191 \\
(.011)\end{array}$ & $\begin{array}{l}.190 \\
(.011)\end{array}$ \\
\hline CONSTANT & $\begin{array}{c}-96530 * * \\
(23524)\end{array}$ & $\begin{array}{c}*-95145^{* *} \\
(23614)\end{array}$ & $\begin{array}{l}-.422 * * \\
(.119)\end{array}$ & $\begin{array}{c}-.414^{* *} \\
(.119)\end{array}$ \\
\hline
\end{tabular}

$\begin{array}{lllll}\text { Log-likelihood } & -2219 & -2219 & -40.98 & -39.95\end{array}$

$\begin{array}{lllll}\text { n } & 312 & 312 & 312 & 312\end{array}$

*Statistically significant at the .05 level; **at the .01 level (2-tailed tests).

an the tobit equation the error term is scaled by an unknown parameter.

The coefficient reported here is the estimate of the scale parameter. ence in contingent pay between the men and women in this sample.

\section{Discussion and Conclusions}

We have analyzed the gender-pay gap by form of pay using new data from a survey of business school graduates. We take a new approach to the analysis of the gender-pay gap. Rather than focusing on the righthand-side variables in the earnings equation, we examine the pay gap by type of pay.

The principal finding of the analysis is that a significant portion of the gap in total pay is due to differences in that part of total pay that is contingent on job performance. The gender difference in contingent pay accounts for $58 \%$ of the $\$ 14,500$ gender difference in average total pay in the sample; gender differences in base pay account for only $42 \%$. When human capital, individual characteristics, and occupation and job level are controlled for, it appears that approximately $34 \%$ of the unadjusted gap in total pay that is not explained by gender differences in endowments is due to gender differences in contingent pay. We believe these results are interesting and informative about a dimension of the gender-pay gap that has previously received very little attention.

This study has some clear limitations. Because the data set is small and was drawn from a rather narrow segment of the population, we cannot extrapolate the results from this study to the entire population. The results from the estimates of the totalpay model, however, are consistent with results from studies that rely on broader and larger samples and include controls for narrowly defined occupations.

Although we stated no predictions concerning the relationship between the gender-pay gap and the form of pay, we will here explore several possible explanations of the findings. The large within-job difference in contingent pay estimated in this data set, controlling for those factors that explain all of the differences in base pay, might occur within firms or across firms. Since we do not have a control for the firm in this study, we cannot test whether this is 
a within-firm or across-firm effect. Possible explanations for the within-job difference in contingent pay vary, however, depending on where the difference occurs.

If gender differences in contingent pay, within jobs, occur within firms, the causes must be one or more of the following. First, firms may not offer men and women equal opportunities to gain contingent pay. Second, men and women may be treated differently in job performance evaluations that are used to determine contingent pay. And third, there may be differences between men and women in their marginal levels of job performance. One of these causes or some combination of them would explain a within-firm, within-job, difference in contingent pay.

Given the findings of previous studies, however, we believe that the observed difference in contingent pay more likely occurs across firms than within firms. As mentioned above, previous studies in which controls for the firm are included have found that within narrowly defined occupations, gender differences in pay occur across firms rather than within firms (for example, Blau 1975; Groshen 1991). These studies have found that within jobs, women are disproportionately represented in lowerpaying firms. If the difference found in this study occurs across firms, then otherwise equally qualified women must be more likely to be employed in firms with lower levels of contingent pay. To explain why women are over-represented in firms with lower levels of contingent pay, we must focus on the sorting mechanisms that cause this particular distribution of employment. It is possible, for example, that firms that rely on contingent pay incentive mechanisms also use recruitment, selection, and career development mechanisms that sort women out of the jobs providing opportunities for high levels of contingent pay.

Finally, one possible explanation for the findings in this study is that women prefer less pay risk than do men and they are more likely than men to choose those occupations and firms, everything else being equal, that offer compensation plans with less variation in pay between pay periods. At least part of the observed difference in total pay between men and women, therefore, may reflect a premium to men for bearing more of the risk of short-run variations in their job performance than, on average, women bear. This interpretation of the results is consistent with the findings of Subich et al. (1989) that women are less willing to take risks in the job market than are men. Further support for this conclusion can be found in studies comparing the risk-taking behavior of men and women within specific jobs and occupations. Muldrow and Bayton (1979) compared several dimensions of the decision making process of male and female executives and found that the decisions of the women in the study were significantly less risky than were those of the men. Sexton and Bowman-Upton (1991) tested the psychological traits of male and female entrepreneurs whose firms were of similar size. Among the very few differences that were found between the men and the women tested was a significantly higher score on risk aversion for the women.

This interpretation is also consistent with the findings of Dreher and Ash (1990). Using the same data set we have used, and controlling for many of the same individual, firm, and job characteristics held constant in our analysis, Dreher and Ash found that the men and women in this sample were equally satisfied with their level of pay despite the significant difference in total pay. ${ }^{7}$

One problem with this explanation is that if the difference represents a risk premium, then we would expect base pay to be lower for men than for women. Our findings indicate that, all else equal, base pay is equal. The results for the decomposition of the difference in base pay reported in Table 5, based on the model controlling for promotions and supervisory responsibilities, do indicate, however, that the coefficients have a positive effect on women's pay relative to men's pay. The coefficient effect is $-3 \%$, meaning that $3 \%$ of the differential in base pay cannot be explained by

\footnotetext{
${ }^{7}$ Dreher and Ash looked only at total pay in their analysis of pay satisfaction.
} 
differences in means, and that this unexplained 3\% favors women's pay. Although the direction of this coefficient effect would be consistent with men accepting lower base pay in exchange for higher (and riskier) expected returns on contingent pay, $3 \%$ of the unadjusted difference is too small to be meaningful in an economic sense. Given such a small difference in base pay, we would expect even highly risk-averse workers to be willing to choose firms using contingent pay mechanisms.

Obviously, the reason why such a large part of the unexplained gender difference in total pay can be accounted for by the gender difference in contingent pay is not clear. Regardless of whether the difference is due to risk preferences, it is clear that within this sample most of the unexplained difference in pay, within jobs, is due to that part of pay that is at risk. This finding poses important questions for future research. First, does the relationship observed here between the gender-pay gap and contingent pay hold within other narrowly defined occupations? Second, does this relationship hold for differences in pay that occur across occupations? Finally, do differences in risk preferences between men and women explain any of the pay difference? -And if so, to what extent is this difference in taste caused by pre-market socialization and education processes, or by women's response to their treatment in the labor market or how they expect to be treated there? A better understanding of why differences in contingent pay can account for so much of the difference in total pay is necessary in order to determine how labor market policy can or cannot affect the gender-pay gap.

\section{REFERENCES}

Abowd, John M. 1990. "Does Performance-Based Managerial Compensation Affect Corporate Performance?" Industrial and Labor Relations Review, Vol. 43, No. 3 (February), pp. S52-S73.

Becker, Gary S. 1971. The Economics of Discrimination, 2nd ed. Chicago: University of Chicago Press. 1985. "Human Capital, Effort, and the Sexual Division of Labor." Journal of LaborEconomics, Vol. 3, No. 1, Part 2 (January), pp. S33-S58.

Blau, Francine D. 1977. Equal Pay in the Office. Lexington, Mass.: D.C. Heath.

Blau, Francine D., and Marianne A. Ferber. 1987a. "Discrimination: Empirical Evidence from the United States." American Economic Review, Vol. 77, No. 2 (May), pp. 316-20.

1987b. The Economics of Men, Women and Work. Englewood Cliffs, N.J.: Prentice-Hall.

Blinder, Alan S. 1973. "Wage Discrimination: Reduced Form and Structural Equations." Journal of Human Resources, Vol. 8, No. 4 (Fall), pp. 436-55.

Brown, Charles. 1990. "Firms' Choice of Method of Pay." Industrial and Labor Relations Review, Vol. 43, No. 3 (February), pp. S165-S182.

Cain, Glen G. 1986. "The Economic Analysis of Labor Market Discrimination: A Survey." In O. Ashenfelter and R. Layard, eds., Handbook of Labor Economics. Amsterdam: North-Holland, pp. 693785.

Dreher, George F., and Ronald A. Ash. 1990. “A Comparative Study of Mentoring Among Men and Women in Managerial, Professional, and Technical
Positions." Journal of Applied Psychology, Vol. 75, No. 5 (October), pp. 539-46.

Gerhart, Barry. 1990. "Gender Differences in Current and Starting Salaries: The Role of Performance, College Major, and Job Title." Industrial and Labor Relations Review, Vol. 43, No. 4 (April), pp. 418-33.

Goldin, Claudia, 1986. "Monitoring Costs and Occupational Segregation by Sex: A Historical Analysis." Journal of Labor Economics, Vol. 4, No. 1 (January), pp. 1-27.

Groshen, Erica L. 1991. "The Structure of the Female/Male Wage Differential." Journal of Human Resources, Vol. 26, No. 3 (Summer), pp. 457-72.

Gunderson, Morley. 1989. "Male-Female Wage Differentials and Policy Responses." Journal of Economic Literature, Vol. 27, No. 1 (March), pp. 46-72.

Hersch, Joni. 1991. "Male-Female Differences in Hourly Wages: The Role of Human Capital, Working Conditions, and Housework." Industrial and Labor Relations Review, Vol. 44, No. 4 (July), pp. 74659.

Kahn, Lawrence M., and Peter D. Sherer. 1990. "Contingent Pay and Managerial Performance." Industrial and Labor Relations Review, Vol. 43, No. 3 (February), pp. 107-20.

Kram, Kathy E. 1985. Mentoring at Work: Developmental Relationships in Organizational Life. Glenview, Ill.: Scott, Foresman.

Lazear, Edward P. 1986. "Salaries and Piece-Rates." Journal of Business, Vol. 59, No. 3 (July), pp. 405-31. 
Muldrow, Tressie W., and James A. Bayton. 1979. "Men and Women Executives and Processes Related to Decision Accuracy." Journal of Applied Psychology, Vol. 64, No. 2 (April), pp. 99-106.

Noe, Raymond A. 1986. "An Investigation of the Determinants of Successful Assigned Mentoring Relationships." Personnel Psychology, Vol. 41, No. 3 (Autumn), pp. 457-79.

Sexton, Donald L., and Nancy Bowman-Upton. 1991. "Female and Male Entrepreneurs: Psychological Characteristics and Their Role in Gender-Related Discrimination." Journal of Business Venturing, Vol. 5, No. 1 (January), pp. 29-36.
Subich, Linda Mezydlo, Gerald V. Barrett, Dennis Doverspike, and Ralph A. Alexander. 1989. "The Effects of Sex-Role-Related Factors on Occupational Choice and Salary." In Robert T. Michael, Heidi I. Hartmann, and Brigid O'Farrell, eds., Pay Equity: Empirical Inquiries. Washington, D.C.: National Academy Press.

Whitely, William., Thomas W. Dougherty, and George F. Dreher. 1988. "The Relationship of Mentoring and Socioeconomic Origin to Managers' and Professionals' Early Career Progress." Academy of Management Best Paper Proceedings (August), pp. 58-62. 